\title{
PENGEMBANGAN BAHAN BACAAN CERITA BERGAMBAR BERORIENTASI PENDIDIKAN KARAKTER UNTUK PEMBELAJARAN MEMBACA SISWA KELAS II SD
}

\author{
Nurliani Maulida \\ Universitas Balikpapan \\ Nurlianimaulida46@gmail.com
}

\begin{abstract}
ABSTRAK
Penelitian ini bertujuan untuk menghasilkan bahan bacaan cerita bergambar berorientasi pendidikan karakter untuk pembelajaran membaca siswa kelas II SD yang berkualitas dan layak digunakan dalam proses pembelajaran serta mendeskripsikan kualitas hasil pengembangan produk bacaan tersebut, serta mengungkapkan persentase ketuntasan belajar siswa setelah menggunakan produk bacaan yang dikembangkan. Penelitian ini merupakan penelitian pengembangan. Prosedur pengembangan dalam penelitian ini meliputi: (1) analisis kebutuhan; (2) pengembangan desain produk bahan bacaan; (3) produksi; (4) uji coba dan revisi; serta (5) implementasi produk akhir. Uji coba dilaksanakan di SD Negeri 020 Balikpapan Utara dan SD Negeri 004 Balikpapan Utara dengan dua guru yang berbeda. Instrument penelitian yang digunakan adalah lembar validasi, lembar penilaian guru, lembar angket siswa, dan tes hasil belajar. Analisis data kevalidan dan kepraktisan dilakukan dengan cara mengkonversi data kuantitatif berupa skor hasil penilaian menjadi data kualitatif berupa nilai standar skala lima. Hasil penelitian menunjukkan bahwa kualitas produk bahan bacaan cerita bergambar berorientasi pendidikan karakter untuk pembelajaran membaca siswa kelas II SD termasuk dalam kategori baik, dengan rerata skor 4,3 dari rentang nilai 1-5. Aspek pembelajaran menunjukkan rerata skor 4,2; aspek isi rerata skor 4,8; aspek tampilan rerata skor 4,8. Hasil tes belajar siswa rata-rata nilai sudah mencapai ketuntasan. Penggunaan bahan bacaan ini berdampak baik terhadap ketuntasan belajar siswa. Dari 60 siswa, semua siswa mendapat nilai baik dan mencapai standar ketuntasan belajar minimal, yaitu memperoleh nilai 70. Dengan demikian, produk bacaan tersebut sudah layak digunakan pada saat pembelajaran membaca.
\end{abstract}

Kata Kunci: bahan bacaan, berorientasi karakter, siswa kelas II $S D$

ABSTRACT

This study aims to produce picture story reading materials with character education orientation for grade II SD students who are qualified and fit to be used in the learning process and to describe the quality of the reading product development result, and to reveal the percentage of students' learning mastery after using the developed reading product. This research is a development research. Procedures of development in this study include: (1) 
needs analysis; (2) development of product design of reading material; (3) production; (4) trial and revision; and (5) implementation of the final product. The trial was conducted at SD Negeri 020 Balikpapan Utara and SD Negeri 004 North Balikpapan with two different teachers. The research instrument used was validation sheet, teacher's appraisal sheet, student questionnaire, and test of learning result. Data analysis of validity and practicability is done by converting quantitative data in the form of scores of assessment results into qualitative data in the form of standard scores five scale. The result of the research shows that the quality of the reading character-oriented picture-reading material for the reading of grade II elementary students is included in the good category, with the average score of 4.3 from the range of 1-5 values. The learning aspect shows a mean score of 4.2 ; aspect contents average score 4.8; aspect display average score 4.8. The results of the student's learning test average value has reached completeness. The use of reading material has a good impact on students' learning mastery. Of the 60 students, all students get good grades and achieve a minimum learning mastery standard, which is getting a value of 70 . Thus, the reading product is feasible to use

Keywords: reading material, character oriented, second grade students of elementary school

Membaca merupakan keterampilan mengenal dan memahami tulisan dalam bentuk urutan lambang-lambang grafis dan perubahannya menjadi wicara bermakna dalam bentuk pemahaman diam-diam atau pengujaran keras-keras (Kridalaksana, 2008:135). Pemahaman bahan bacaan tidak bisa dilepaskan dari proses belajar. Proses belajar suatu bacaan dapat dilihat dari nilai-nilai yang diperoleh siswa. Pemahaman makna dari suatu bacaan merupakan tujuan utama dari aktivitas membaca. Dengan kata lain, ketika membaca, pembaca juga harus dapat memahami makna dan isi dari bacaan tersebut.

Penerapan bahan bacaan cerita bergambar berorientasi pada pendidikan karakter dalam pelajaran membaca sampai saat ini belum dapat terlaksana seperti yang diharapkan. Salah satu faktor penyebabnya adalah kurang tersedianya media atau sumber belajar untuk pelajaran membaca dengan cerita bergambar. Perangkat pembelajaran bahasa Indonesia dalam keterampilan membaca yang tersedia di lapangan masih sangat terbatas dan penggunaannya belum optimal.

Penelitian yang dilakukan Suzanne, M (2007), dalam penelitiannya yang berjudul "Developing Children's Interest in Reading”. Penelitian yang berkaitan dengan judul di atas merupakan penelitian studi kasus yang meneliti tentang membaca. Perbedaaan dengan penelitian ini, penelitian di atas hanya memfokuskan penelitian untuk mengetahui ketertarikan dan minat membaca siswa, sedangkan penelitian ini mengembangkan produk bacaan untuk siswa kelas II SD. 
Membaca dapat didefinisikan sebagai penafsiran yang bermakna terhadap bahasa tulis (Zuchdi, 2008:19). Sejalan dengan Zuchdi, Grabe (2009:14) menyebutkan bahwa reading is the process of receiving and interpreting information encoded in language form via the medium of print. Pernyataan Grabe tersebut menunjukkan bahwa membaca adalah proses menerima dan menginterpretasi informasi dalam bentuk bahasa lewat media cetak. Proses membaca melibatkan dua entitas fisik yang sangat diperlukan dalam memulai proses tersebut, antara lain teks dan pembaca. Satu hal yang penting dan tidak bisa dihindari adalah interaksi antara pembaca dan teks selama proses tersebut berlangsung untuk memahami makna yang tersurat dan tersirat yang ingin disampaikan oleh penulis teks tersebut. Lewat membaca seseorang berusaha untuk menemukan apa yang ada di dalam teks atau mengikuti pikiran pengarang.

Cerita bergambar merupakan salah satu media pendidikan dalam membantu kegiatan pembelajaran yang mempunyai fungsi, nilai, dan karakteristik, sehingga perlu adanya kriteria yang dapat digunakan sebagai acuan. Kriteria pemilihan media gambar disesuaikan dengan tujuan yang akan dicapai dengan teknik yang akan digunakan dan disesuaikan dengan kematangan siswa.

Pendidikan karakter bertujuan untuk meningkatkan mutu penyelenggaraan dan hasil pendidikan di sekolah yang mengarah pada pencapaian pembentukan karakter atau akhlak mulia peserta didik secara utuh, terpadu, dan seimbang, sesuai standar kompetensi lulusan (Kemendiknas, 2010c:8). Melalui pendidikan karakter diharapkan peserta didik pada jenjang menengah pertama mampu secara mandiri meningkatkan dan menggunakan pengetahuannya, mengkaji dan menginternalisasi serta mempersonalisasi nilai-nilai karakter dan akhlak mulia sehingga terwujud dalam perilaku sehari-hari.

Proses pengintegrasian nilai-nilai karakter dalam bahan bacaan dapat dijabarkan secara terpadu dengan berpatokan pada tema-tema yang telah ditentukan seperti, gemar membaca, disiplin, rasa ingin tahu, dan kejujuran. Zuchdi (2011:220) mengatakan bahwa dengan adanya keterampilan membaca secara kolektif akan terbentuk masyarakat yang tidak mudah terprovokasi, tidak bertindak reaktif dan emosional, mampu menguasai diri, karena biasa bersikap kritis, selalu menilai secara cermat kebenaran setiap informasi yang mereka terima. Dengan kata lain, akan terbentuklah kehidupan yang cerdas secara intelektual dan emosional.

METODE

Penelitian yang dilakukan menggunakan model penelitian dan pengembangan atau Research and Development (R\&D), bertujuan untuk mengembangkan dan memvalidasi produk bahan bacaan cerita bergambar berorientasi pendidikan karakter untuk pelajaran membaca siswa kelas II SD yang layak dimanfaatkan dan sesuai dengan kebutuhan. Penelitian pengembangan banyak digunakan dalam mengatasi permasalahan praktis di dunia pendidikan. Penelitian dengan model pengembangan dipilih karena dilakukan 
dengan berorientasi pada produk. Hasil akhir produk bertujuan untuk membangun karakter anak menggunakan bahan bacaan.

Prosedur penelitian pengembangan pada dasarmya terdiri dari dua tujuan utama, yaitu: mengembangkan produk dan menguji kelayakan produk untuk digunakan sebagai bahan bacaan untuk siswa. Prosedur pengembangan bahan bacaan ini diadaptasi dari Borg \& Gall (2007:590). Produk yang dihasilkan berupa buku bacaan yang berorientasi pendidikan karakter untuk pembelajaran membaca siswa kelas II SD terdiri dari analisis, desain pengembangan, uji coba dan revisi, produk akhir.

Pada saat uji coba lapangan melibatkan tiga puluh siswa serta guru SD Negeri 020 Balikpapan Utara dan SD Negeri 004 Balikpapan Utara. Guru yang dilibatkan dalam uji coba kelompok kecil dilibatkan kembali pada uji coba lapangan. Siswa yang dilibatkan dalam uji coba lapangan ada enam puluh siswa dan masing-masing kriteria diwakilkan sepuluh siswa.

Teknik analisis data menggunakan teknik analisis deskriptif kuantitatif. Data yang dianalisis meliputi analisis kelayakan produk oleh ahli materi, ahli media, guru kelas II SD, dan siswa kelas II SD. Teknik analisis data untuk kelayakan terhadap bahan bacaan, dilakukan dengan menggunakan rumus berikut ini (Sugiyono, 2008:81).

$$
M=\frac{\sum \mathrm{X}}{\mathrm{N}}
$$

\section{Keterangan:}

$M=$ Mean yang dicari.

$\sum \mathrm{X}=$ Jumlah dari skor-skor (nilai-nilai) yang ada.

$\mathrm{N}=$ Number of Case (banyaknya skor-skor itu sendiri).

Kualitas hasil pengembangan baik dari para ahli, guru Bahasa Indonesia, serta untuk mengetahui penilaian siswa terhadap modul, maka data yang mula-mula berupa skor, diubah menjadi data kualitatif (data interval) dengan skala tiga. Adapun acuan pengubahan skor menjadi skala tiga tersebut ditentukan terlebih dahulu kriteria nilai dan batas-batasnya sesuai dengan norma kategorisasi yang telah diubah menjadi kriteria konversi nilai, sebagai berikut.

Tabel 1

Pedoman Konversi Nilai

\begin{tabular}{|c|c|}
\hline Formula & Kategori \\
\hline$X<(\mu-1,0 \sigma)$ & Kurang \\
\hline$(\mu-1,0 \sigma) \leq X<(\mu+1,0 \sigma)$ & Cukup \\
\hline$(\mu+1,0 \sigma) \leq X$ & Baik \\
\hline
\end{tabular}

Keterangan:

$\mathrm{X}=$ jumlah skor subjek

$\mu=$ mean ideal 


$$
\begin{aligned}
& =\text { jumlah aitem } \times \frac{\text { skor tertinggi }+ \text { skor terendah }}{2} \\
\sigma & =\text { standar devisiasi ideal } \\
& =\frac{[(\text { jumlah aitem } \times \text { skor tertinggi })-(\text { jumlah aitem } \times \text { skor terendah })]}{6}
\end{aligned}
$$

Dalam penelitian ini kelayakan ditentukan dengan nilai minimal berketegori cukup. Jadi, jika hasil penilaian oleh ahli, guru kelas II Sekolah Dasar, dan siswa kelas II SD reratanya memberikan hasil akhir berkategori cukup, maka produk pengembangan modul sudah diaggap layak digunakan.

\section{PEMBAHASAN}

Pengembangan bahan bacaan cerita bergambar yang dilakukan dalam penelitian ini meliputi lima langkah utama, yaitu pendahuluan, pengembangan produk, evaluasi produk, dan produk akhir yaitu berupa bahan bacaan cerita bergambar berorientasi pendidikan karakter. Secara rinci, langkah pengembangan tersebut sebagai berikut.

Langkah pertama adalah pendahuluan yang berisi analisis kebutuhan pengembangan dilakukan untuk mendapatkan informasi tentang sejauh mana bahan bacaan ini dibutuhkan dalam pengoptimalkan pembelajaran membaca. Data pada langkah pertama ini diambil dari studi pustaka dan analisis kompetensi melalui pengamatan terbatas pada guru kelas II Sekolah Dasar. Tahap analisis kebutuhan dilakukan pada tanggal 7 September 2013 di SD Negeri 020 Balikpapan Utara, pada tanggal 11 September 2013 di SD Negeri 004 Balikpapan Utara. Berikut adalah rincian hasil dari kegiatan kajian teori dan analisis kompetensi. Studi pustaka dilakukan dengan membaca buku materi untuk pelajaran Bahasa Indonesia yang ada di kelas II SD. Buku-buku yang digunakan di dalam pembelajaran dianalisis untuk mengetahui kesesuaian dan kelengkapan materi yang disajikan. Selain itu, guru kelas II sangat membutuhkan buku pedoman untuk menunjang pembelajaran di dalam kelas. Materi ajar merupakan komponen yang tidak bisa ditinggalkan dalam sebuah pembelajaran, tanpa adanya materi ajar pembelajaran tidak akan berlangsung.

Berdasarkan studi pustaka, diketahui bahwa buku-buku yang digunakan di sekolah-sekolah, yaitu buku dari penerbit Erlangga dan bse untuk pelajaran bahasa Indonesia dalam hal pembejaran membaca sangat memerlukan prioritas pengembangan. Materi yang terdapat dalam buku-buku khususnya cerita yang disajikan di dalam pembelajaran membaca masih kurang. Selain itu, cerita yang ada di dalam buku paket belum berkarakter.

Wawancara kepada guru bertujuan untuk mengetahui informasi mengenai buku yang dipakai dan kendala yang ditemukan pada saat pelajaran Bahasa Indonesia khususnya untuk pembelajaran membaca. Hasil wawancara dengan dua guru sekolah dasar mengenai pelajaran Bahasa Indonesia khususnya membaca siswa 
masih kesulitan. Hal itu diperkuat dari komentar guru sebagai berikut.

"Namun, ada beberapa siswa yang masih kurang cepat dalam memahami pelajaran. Siswa di kelas tempat saya tergolong menjadi tiga kriteria, yaitu tinggi, sedang, dan rendah. Oleh karena itu, terkadang pada saat pembelajaran khususnya membaca masih ada yang kesulitan”.

Selain itu, guru menggunakan buku paket yang ada disekolah dan tidak ada buku pendamping yang lain untuk pembelajaran membaca. Hal itu diperkuat dengan komentar guru berikut.

"Saya di kelas menggunakan buku paket yang dibagikan dari Kementrian Pendidikan dan Kebudayaan”.

Hasil wawancara selanjutnya berkaitan dengan penggunaan buku paket yang kurang menarik untuk siswa. Buku paket yang digunakan membuat siswa merasa bosan dengan pembelajaran membaca. Hal itu diperkuat dengan komentar guru berikut.

"Siswa merasa buku yang digunakan kurang menarik dan cerita yang ada di dalam buku sedikit. Selain itu, ceritanya tidak menarik untuk dibaca.”

Berdasarkan komentar tersebut, dapat terlihat jika bahan bacaan yang digunakan siswa kurang menarik sehingga siswa kurang menyukai pembelajaran membaca.

Analisis kompetensi dilakukan dengan menganalisis kurikulum dan materi pelajaran Bahasa Indonesia kelas II SD. Dipilih beberapa kompetensi dasar yang menjadi sarana pengembangan. Dalam penelitian ini, dipilih jenis pembelajaran membaca untuk memahami ragam wacana tulis dengan membaca nyaring dan membaca dalam hati baik dari kurikulum KTSP maupun kurikulum 2013. Kompetensi tersebut, kompetensi dasar dalam pembelajaran membaca untuk memahami ragam wacana tulis dengan membaca nyaring dan membaca dalam hati berikut ini standar komepetensi pembelajaran membaca di kelas II SD berdasarkan kurikulum KTSP dan kurikulum 2013.

Tabel 2

Standar Kompetensi Pembelajaran Membaca di Kelas II SD Kurikulum KTSP dan Kurikulum 2013

\begin{tabular}{|c|l|}
\hline Kurikulum & \multicolumn{1}{|c|}{ Standar Kompetensi } \\
\hline \multirow{2}{*}{$\begin{array}{c}\text { Kurikulum } \\
\mathbf{2 0 1 3}\end{array}$} & $\begin{array}{l}\text { Gemar menggali informasi melalui membaca } \\
\text { dan mendengarkan dari sumber lain berdasarkan } \\
\text { rasa ingin tahu }\end{array}$ \\
\cline { 2 - 2 } & $\begin{array}{l}\text { Membacakan kalimat sederhana dan puisi anak- } \\
\text { anak (dengan lafal dan intonasi yang tepat) dan } \\
\text { menjelaskan isi }\end{array}$ \\
\hline
\end{tabular}




\begin{tabular}{|c|l|}
\hline Kurikulum & \multicolumn{1}{|c|}{ Standar Kompetensi } \\
\hline & $\begin{array}{l}\text { Menerapkan cara membaca (permulaan) dengan } \\
\text { cara yang benar (cara duduk, jarak mata dan } \\
\text { buku, cara memegang buku, cara membalik } \\
\text { halaman buku, memilih tempat dengan cahaya } \\
\text { yang terang) }\end{array}$ \\
\hline \multirow{2}{*}{$\begin{array}{c}\text { Kurikulum } \\
\text { KTSP }\end{array}$} & $\begin{array}{l}\text { Memahami ragam wacana tulis dengan membaca } \\
\text { nyaring dan membaca dalam hati }\end{array}$ \\
\cline { 2 - 2 } & $\begin{array}{l}\text { Memahami teks pendek dengan membaca lancar } \\
\text { dan membaca puisi anak. }\end{array}$ \\
\hline
\end{tabular}

Berdasarkan tabel mengenai kurikulum yang digunakan di sekolah dasar, dapat terlihat dalam pembelajaran membaca terdapat beberapa poin mengenai kompetensi dasar yang sesuai dengan produk yang dikembangkan. Di dalam kurikulum KTSP, standar kompetensi untuk produk ini adalah memahami teks pendek dengan membaca lancar dan membaca puisi anak dan memahami ragam wacana tulis dengan membaca nyaring dan membaca dalam hati. Selain itu, produk bacaan yang dihasilkan dapat juga digunakan pada kurikulum 2013.

Berdasarkan analisis kurikulum yang ada dapat dikatakan bahwa buku produk bacaan yang dikembangkan dapat dipakai dalam kurikulum KTSP dan kurikulum 2013. Hal itu terlihat dari kompetensi dasar/kompetensi inti memiliki kesesuaian dengan apa yang dihasilkan dari produk ini.

Tahap kedua adalah tahap pengembangan produk. Pada tahap ini berdasarkan hasil dari analisis kebutuhan dijadikan sebagai dasar pengembangan produk. Produk yang dikembangkan dirancang sedemikian rupa agar dapat digunakan pada kurikulum KTSP maupun kurikulum 2013. Produk yang dikembangkan juga dapat digunakan pada pembelajaran membaca semester satu dan dua. Hasil yang diperoleh dari tahap ini adalah sebagai berikut.

Penetapan materi pokok disesuaikan dengan kurikulum yang digunakan untuk pembelajaran di sekolah. Materi membaca membutuhkan bahan bacaan untuk memudahkan siswa memahami isi cerita. Cerita yang akan dikembangkan merupakan cerita yang bernilai karakter dengan beberapa gambar untuk memperjelas isi dari cerita. Cerita yang disajikan dalam produk bacaan yang dikembangkan berisi empat nilai karakter. Empat cerita yang disajikan disesuaikan dengan kondisi siswa dan kehidupan seharihari. Materi di dalam buku bacaan dikembangkan sesuai dengan karakter yang ingin dicapai untuk siswa kelas II SD. Materi yang tercantum di buku bacaan tersebut membantu siswa untuk memahami karakter yang ada. Materi yang dikembangkan dalam produk bahan bacaan ini adalah (a) gemar membaca, (b) disiplin, (c) rasa ingin tahu, dan (d) kejujuran.

Standar kompetensi untuk pengembangan produk bahan bacaan ini disesuaikan dengan standar kompetensi kurikulum yang dipakai agar produk yang dihasilkan bisa digunakan dalam pembelajaran di kelas. Kurikulum KTSP dan kurikulum 2013 memiliki beberapa 
standar kompetensi. Standar kompetensi dasar yang sesuai dengan pembelajaran membaca. standar kompetensi dapat terlihat bahwa kurikulum KTSP dan kurikulum 2013 memiliki maksud dan tujuan yang sama. Standar kompetensi yang sesuai untuk produk pengembangan ini adalah gemar menggali informasi melalui ragam wacana tulis dengan membaca nyaring dan membaca dalam hati. Kompetensi dasar yang sesuai dengan produk pengembangan ini adalah Membaca nyaring teks (15-20 kalimat) dengan memperhatikan lafal dan intonasi yang tepat.

Uji coba produk dibagi menjadi tiga bagian, yaitu uji coba oleh ahli, guru kelas II SD, dan siswa SD. Evaluasi tahap pertama dilakukan oleh ahli materi dan ahli media. Hasil validasi oleh ahli materi dan ahli media selanjutnya dilakukan analisis. Masukan pada evaluasi pertama digunakan sebagai dasar revisi produk tahap I. Hasil evaluasi produk, selanjutnya dilakukan uji coba kelompok kecil oleh siswa kelas II SD dan evaluasi dari guru. Uji coba oleh siswa kelas II SD dilakukan di SD Negeri 020 Balikpapan Utara dan SD Negeri 004 Balikpapan Utara. Evaluasi produk oleh siswa dan guru selanjutnya dilakukan analisis dan revisi tahap II. Masukan pada evaluasi kedua digunakan sebagai dasar revisi produk tahap II. Hasil evaluasi produk, selanjutnya dilakukan uji coba lapangan. Evaluasi produk oleh siswa dan guru selanjutnya dilakukan analisis revisi, dan menghasilkan produk akhir.

Sebelum dilaksanakan uji coba untuk mengetahui kelayakan produk media dari sisi materi dan media perlu mendapatkan validasi dari ahli materi dan ahli media. Evaluasi materi dilaksanakan oleh dosen pengampu mata kuliah pembelajaran bahasa, sedangkan evaluasi media dilaksanakan oleh dosen pengampu mata kuliah Multimedia Pembelajaran. Para ahli memberikan validasi terhadap produk secara terstruktur dengan memberikan data kualitatif berupa lembar validasi. Hasil uji coba produk dalam pengembangan bahan bacaan cerita bergambar dilakukan dalam 2 tahap uji coba. Tahap pertama small group evaluation (uji coba kelompok kecil) dan field test evaluation (uji coba lapangan).

Revisi ini dilakukan berdasarkan saran ahli materi, ahli media, guru dan angket siswa, selain itu juga berdasarkan temuan dilapangan yaitu pada saat uji coba dikelompok kecil maupun uji coba lapangan. Revisi yang dilakukan terdiri dari tiga kali, revisi pertama dilakukan setelah dapat saran dari ahli baik ahli materi maupun juga ahli media, revisi kedua dilakukan setelah diperoleh temuan uji kelompok kecil, selanjutnya revisi ketiga dilakukan setelah diperoleh temuan dari uji coba lapangan.

Berdasarkan hasil uji coba para ahli, uji coba kelompok kecil, dan uji coba lapangan, diketahui bahwa terjadi peningkatan penilaian terhadap produk yang dikembangkan. Hal ini dapat diartikan bahwa revisi terhadap produk yang dikembangkan membawa hasil yang positif terhadap produk yang dikembangkan. Dengan demikian, evaluasi dan revisi sangat diperlukan untuk meningkatkan kualitas produk bahan bacaan yang dikembangkan 
sehingga menghasilkan media yang berkualitas baik dari segi pembelajaran dan tampilan.

Produk bahan bacaan cerita bergambar berorientasi pendidikan karakter untuk pembelajaran membaca siswa kelas II SD telah selesai dikembangkan dan divalidasi. Langkah-langkah pengembangan model ini melalui lima tahapan, yaitu analisis kebutuhan, desain produk, pengembangan produk bacaan, uji coba dan revisi, dan pemanfaatan. Tahap pengembangan produk bahan bacaan ditempuh dengan langkah-langkah, pembuatan draft model, mengumpulkan bahan-bahan materi SD kelas II, memlilih materi, memasukkan materi sesuai model, dan tes secara modular.

Berdasarkan hasil analisis penilaian guru dan angket siswa terhadap kualitas produk dalam uji coba lapangan, ditinjau dari aspek pembelajaran, isi dan tampilan, diperoleh rata-rata skor 4,0 dan 4,3. Angka ini menurut tabel konversi data kuantitatif ke data kualitatif tergolong pada kriteria "baik". Sesuai dengan kriteria kualitas produk yang telah ditetapkan, yaitu bahwa setiap aspek yang dinilai dalam produk yang dikembangkan dianggap layak jika guru minimal menilai dengan kriteria “cukup” atau "baik”, maka produk bahan bacaan cerita bergambar berorientasi pendidikan karakter untuk pembelajaran membaca siswa kelas II SD dinilai layak, baik dari aspek pembelajaran, aspek isi, dan aspek tampilan.

Berdasarkan komentar ahli materi, ahli media, dan guru baik dalam uji coba kelompok kecil, maupun uji coba lapangan terungkap bahwa proses pembelajaran dengan menggunakan produk bahan bacaan yang dikembangkan ternyata memudahkan siswa dalam memahami materi bacaan, menarik, dan lebih menyenangkan. Berdasarkan hasil pengamatan selama proses uji coba juga menunjukkan bahwa siswa begitu antusias dalam pembelajaran dengan menggunakan produk bacaan yang dikembangkan. Materi pembelajaran dapat dengan mudah dipahami oleh siswa.

\section{SIMPULAN}

Berdasarkan hasil penelitian dan pembahasan diperoleh simpulan sebagai berikut. Produk bahan bacaan cerita bergambar berorientasi pendidikan karakter untuk pembelajaran membaca siswa kelas II SD telah dikembangkan sesuai dengan prosedur pengembangan. Uji coba terhadap produk bahan bacaan cerita bergambar berorientasi pendidikan karakter untuk pembelajaran membaca siswa kelas II SD melalui tahap validasi ahli materi dan ahli media, uji coba kelompok, dan uji coba lapangan, serta analisis dan revisi sehingga menjadi produk akhir yang layak digunakan sebagai media pembelajaran dan buku bacaan.

Kelayakan produk bahan bacaan cerita bergambar berorientasi pendidikan karakter untuk pembelajaran membaca siswa kelas II SD ditinjau dari validasi ahli, penilaian guru, nilai siswa, dan angket siswa. Produk bahan bacaan ditinjau mempunyai dampak baik terhadap ketuntasan hasil belajar siswa terlihat dari nilai siswa yang mencapai KKM dan semuanya tuntas. Karakter yang disajikan 
di dalam bacaan membantu siswa untuk memahami nilai karakter baik dan menanamkan siswa untuk mempunyai karakter baik.

\section{DAFTAR PUSTAKA}

Borg \& Gall. 2007. Educational research : an introduction. New York: Pearson.

Grabe, W. 2009. Reading in a second language: moving from theory to practice. New York: Cambridge University Press.

Kemendiknas. 2010c. Panduan pendidikan karakter di sekolah menengah pertama. Jakarta: Kemendiknas.

Kridalaksana, H. 2008. Kamus Linguistik (Edisi Keempat). Jakarta: PT. Gramedia Pustaka Utama.

Sugiyono. 2008. Metode Penelitian Kuantitatif Kualitatif dan $R \& D$. Bandung: Alfabeta.
Suzanne, M. (2007). Developing Children's Interest in Reading. Journal of Gender Issues in Information Needs and Services, Vol 56, 402-422.

Zuchdi, D. (2011). Terampil membaca karakter mulia.Yogyakarta: UNY Press.

Zuchdi, D. (2011). Bahasa dan sastra Indonesia sebagai wahana pendidikan karakter. dalam Darmiyati Zuchdi (Ed.), Pendidikan karakter dalam perspektif teori dan praktik (p. 220). Yogyakarta: UNY Press. 